\title{
QUINONE PATTERNS AND IDENTIFICATION OF Japanese Spider Leg Sundews (Drosera Sect. Arachnopus)
}

JAN SCHLAUER • Zwischenstr. 11 • D-60594 Frankfurt/Main• Germany • jan@carnivorousplants.org SiegFried R. H. HARTMEYER AND IRMGARD HARTMEYER • Wittlinger Str. 5 • D-79576 Weil am Rhein - Germany•s.hartmeyer@t-online.de

Keywords: Drosera, Phytochemistry, Naphthoquinones, Chemotaxonomy.

Introduction

The Japanese sundews that have previously been collectively called $D$. indica L. (especially after the influential Flora of Japan, Ohwi 1965:492) are being split up. Various authors (e.g., Watanabe 2013) are trying to re-establish or create one or two additional species assumed endemic to Japan, following the contemporary trend to recognize a number of segregate taxa in Drosera sect. Arachnopus (Greek for "spider leg"), the group that contains D. indica. Previous research (Schlauer et al. $2017,2018,2019$ ) has demonstrated a rather unexpected diversity in the naphthoquinones that are characteristic for the different species now recognized in this group. While a few Australian species contain ramentaceone (7-methyljuglone), most contain the regio-isomer plumbagin (2-methyljuglone). So far, only $D$. indica s.str. (accessions from Asia and Africa have been investigated) contains both isomers in the same plant. The morphological diversity found in Japan thus prompted a chemical investigation, the results of which are reported here.

\section{Materials and methods}

Plants of two different accessions informally named "D. makinoi" (with white flowers, seeds with almost isodiametric testa cells; from Tochigi and cultivated by a grower in Kanto district, Japan) and "D. toyoakensis" (pink flowers, seeds with longitudinally compressed testa cells; from Toyohashi and cultivated by a grower in Kansai district, Japan) were raised from seed obtained from Koji Kondo, Kobe, Japan. The methods for cultivation, extraction, separation, and detection of quinones were the same as detailed previously (Schlauer et al. 2018).

\section{Results}

Naphthoquinones were detected in both samples. While the pink flowered taxon contained only plumbagin, the white flowered one contained both plumbagin and ramentaceone.

\section{Discussion}

The pink flowered plant corresponds in all morphological aspects to D. serpens Planch. (petiole present, emergences of insect abdomen, bulls head and bowler-hat types, seed testa cells longitudinally compressed). And, as also the characteristic quinone plumbagin is found in the Japanese plant as well as in several previously investigated samples of $D$. serpens (from Asia and Australia), there remains little reason to separate the Japanese plants from $D$. serpens. The reported localities near the 
towns of Toyoake and Toyohashi (both in Aichi Prefecture, Japan) are thus new records for D. serpens. D. indica f. rosea Makino (1905:24) is probably a synonym, its type locality ("Takashi-mura, Prov. Mikawa", possibly in the Toyohashi area) and another locality given by Makino ("Takatorimura, Aomi-gori”) are both in the same part of Aichi Prefecture.

The white flowered plant is somewhat more difficult to interpret because in emergence morphology (Fig. 1) it coincides with $D$. serpens, while flowers, seeds, and the quinone pattern are more similar to $D$. indica. The plants evidently grow true from seeds, so the plant is fertile and probably not an F1 hybrid. As it seems possible to differentiate it from typical $D$. indica by its indumentum, recognition as a separate taxon may be justified. If it is derived from hybrids between $D$. indica and D. serpens (the hypothesis proposed here) and if the assumed parents are separated at species rank, it cannot be classified as an infraspecific entity under either (as originally done in D. indica f. albiflora Makino, 1905:24; type from Kazusa Prov., now Chiba Pref., Japan). The first validly published name at an appropriate rank would indeed appear to be D. makinoi Masam. (Masamune 1935:11, type from Simotuke/Shimotsuke Prov., now Tochigi Pref., Japan). Considering the large area of geographic overlap of the putative parent species, it is not necessarily confined to Japan. Future

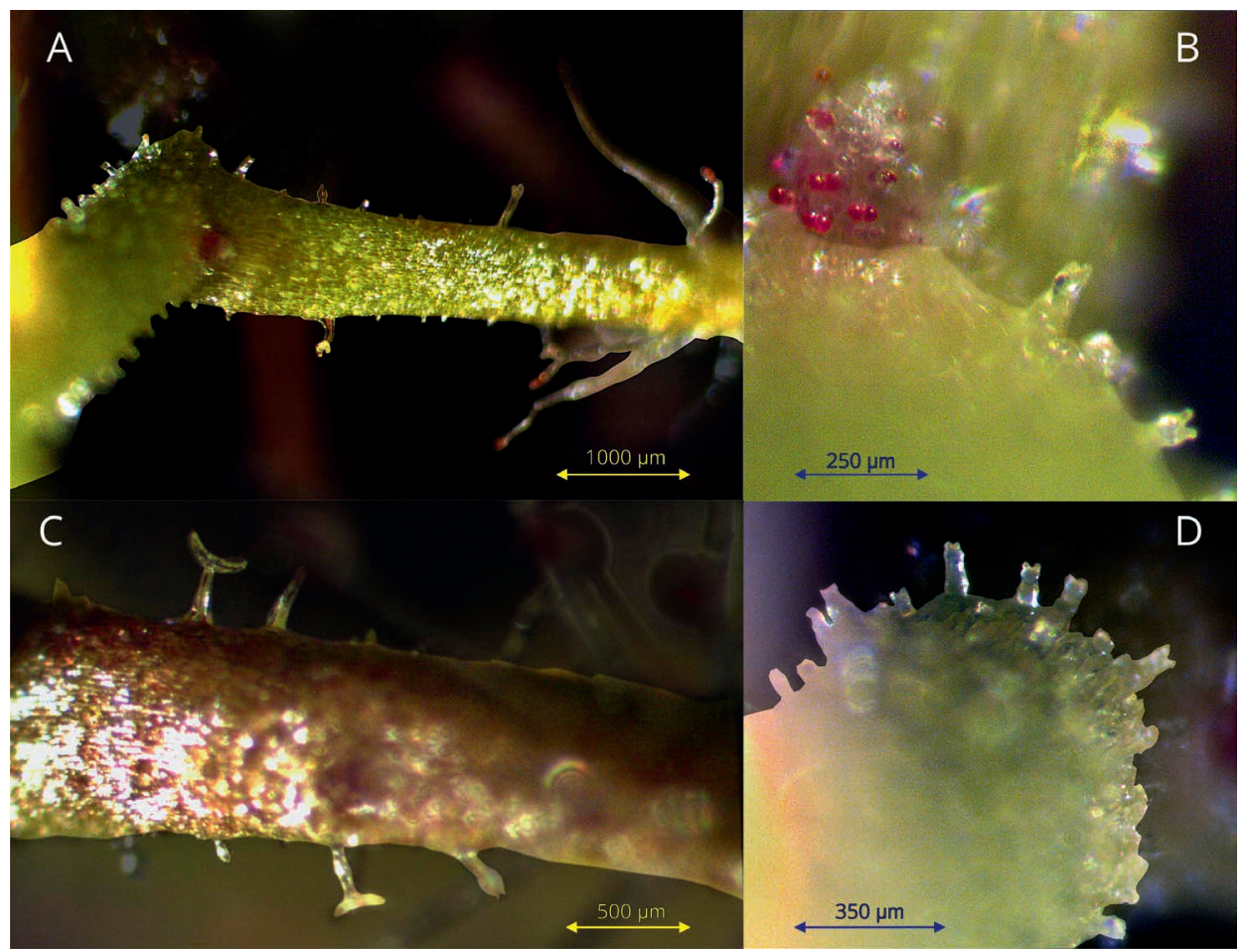

Figure 1: Indumentum of the white flowered sundew taxon assigned to Drosera makinoi. A: leaf base showing petiole with bulls head emergences, double-tipped-cap emergences and (small) insect abdomen emergence; B: bud in leaf axil dotted with red stipitate glands; C: detail of petiole with bulls head emergences, double-tipped-cap emergences and insect abdomen emergence; D: young expanding leaf with double-tipped-cap emergences on lower (abaxial) surface. Cultivated plants, photos by Siegfried R.H. Hartmeyer. 
floristic (and phylogenetic) research in eastern Asia should take this into account. If all plants identified as D. indica f. albiflora in the last revision (Komiya \& Shibata 1994) were indeed D. makinoi, there would not remain a single record of D. indica s. str. from Japan (because all others refer to $D$. serpens), which would entirely overturn the previous concept (Ohwi 1965) that had D. indica as the sole representative of $D$. sect. Arachnopus in Japan.

Acknowledgements: We would like to express our sincere gratitude to Koji Kondo, Kobe, Japan, for providing the seeds of the plants investigated in this study and for valuable locality and literature information, to Tian-Chuan Hsu and Jer-Ming Hu, both Taipei, Taiwan, for tracing the type of $D$. makinoi ("Hab. Isokawa, oppido Hongo, Simotuke", Oct. 5, 1930 [not "Oct. 15, 1930", as printed in the original description], Suzuki-Tokio s.n. (TAI051807)), and to Andreas Fleischmann, Munich, Germany, for correcting the manuscript.

\section{References}

Komiya, S., and Shibata, C. 1994. On Indian Sundew, Drosera indica L. (Droseraceae) (in Japanese). Bulletin of the Nippon Dental College 23: 125-155.

Makino, T. 1905. Observations on the Flora of Japan. Botanical Magazine (Tokyo) 19: 23-30.

Masamune, G. 1935. Beiträge zur Flora von Südjapan (IV). Transactions of the Natural History Society of Formosa 25: 11-16.

Ohwi, J. 1965. Flora of Japan (English translation). Washington: Smithsonian Institution.

Schlauer, J., Hartmeyer, S.R.H., and Hartmeyer, I. 2017. Unexpected discovery of 7-methyljuglone (ramentaceone) in several Australian sundews. Carniv. P1. Newslett. 46: 20-22.

Schlauer, J., Hartmeyer, S.R.H., Hartmeyer, I., Hennern, H., and Hennern, A. 2018. Sundew chemistry and emergence updates. Carniv. Pl. Newslett. 47: 10-17.

Schlauer, J., Hartmeyer, S.R.H., Hartmeyer, I., Hennern, H., and Hennern, A. 2019. New sundew quinone and emergence data. Carniv. Pl. Newslett. 48(1): 6-12.

Watanabe, M. 2013. A New Species Unique to Japan! Biodiversity of Toyoake's Drosera indica Understood (in Japanese). https:/www.aichi-edu.ac.jp/intro/files/rikakyoiku_watanabe mikio_140312.pdf (accessed 26 July 2019).

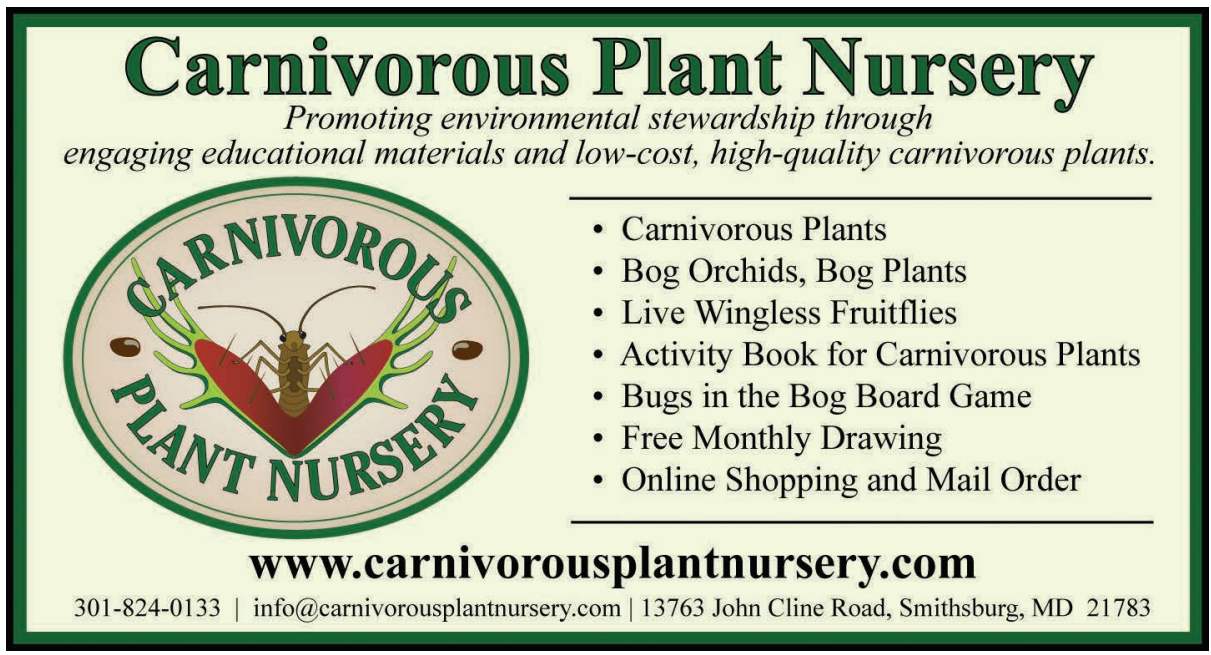

